\title{
Factors Influencing Inflation and Economic Growth in Pakistan: An Econometric Analysis
}

\section{Azra $^{1 *}$, Muhammad Afzal ${ }^{2}$ and Dilawar Khan ${ }^{1}$}

${ }^{1}$ Kohat University of Science and Technology, Kohat, Khyber Pakhtunkhwa, Pakistan; ${ }^{2}$ Preston University, Islamabad, Pakistan.

Abstract | This paper made an econometric investigation of inflation and economic growth in Pakistan for the period 1990-2017. Money supply, imports, exchange rate and budget deficit were the major causes of inflation. Growth in GDP is expected to lead to a reduction in inflation. To combat inflation, unwarranted growth of money supply is checked and the exchange is stabilized. It is less likely that imports are reduced to lessen inflation due to economy needs. It appears difficult that GOP succeeds in curtailing the BD because of the widespread corruption and money-laundering. Human resource development coupled with investment and value-added by both agriculture and industry contributed significantly to economic growth. Should the policy makers attach genuine attention to these factors, it is expected that Pakistan economy will perform reasonably well. Specification and diagnostic tests revealed the appropriateness and soundness of the inflation and economic growth models. Parameters stability was examined for two periods (1991 and 2002). CPI showed stability in both periods but GDP did not demonstrate in the second period.

Received | November 06, 2018; Accepted | June 10, 2020; Published | August 04, 2020

*Correspondence | Azra, Kohat University of Science and Technology, Kohat, Khyber Pakhtunkhwa, Pakistan; Email: azra_alam2009@yahoo.com Citation | Azra, M. Afzal and D. Khan. 2020. Factors influencing inflation and economic growth in Pakistan: An econometric analysis. Sarhad Journal of Agriculture, 36(3): 789-797.

DOI | http://dx.doi.org/10.17582/journal.sja/2020/36.3.789.797

Keywords | Inflation, Economic growth, Money supply, Exchange rate, Pakistan, Jel Classification: E10

\section{Introduction}

$\mathrm{O}$ ver the decades economic growth has remained principal consideration of all countries particularly developing countries. Economic growth was an over-riding objective of development strategy during 1960s. Persistent pursuit of growth was adopted by the developing countries including Pakistan. Keeping aside the long history, economic development of Pakistan has passed through many phases. Pakistan economic situation changed fundamentally in the beginning of the $21^{\text {st }}$ century. Escalating oil prices, energy crisis, adverse security situation and the global economic conditions particularly after global financial crisis in 2007, have necessitated the detailed study of the macro economies of both developed and developing countries. According to GoP (2011-
12) though global financial crisis did not seriously affect Pakistan's economy, Pakistan faced challenges on internal and external fronts notably fight against energy crisis, extremism, and uncertain external inflows.

It is the need of the hour that in the wake of global dynamics, macro-economy of Pakistan is examined in detail. This may enable the policy makers to rethink and recast the growth and development objectives and strategy. Economic growth depends on a large number of social, economic, political, demographic, financial and global factors.

Macroeconomics is based on General Equilibrium approach implying that the economy is influenced by the interplay of all conceivable factors. It is extremely 
difficult that all factors are investigated at length for Pakistan due to several problems like the relative importance and weight of the different sources of growth. This paper singled out to explore the impact of vitalfactors which are most likely to influence inflation and economic growth in Pakistan.

\section{Inflation and economic growth}

Inflation like investment and employment is an important macro variable which is of much concern to policy makers and politicians. Life of the man in the street is greatly influenced by inflation and unemployment. Therefore, governments attach considerable importance to price stability and high employment. Alderman (2005) argued that in developing countries like Pakistan and Nigeria, the living standard was low due to inflation and high inflation reduced food consumption by households that led to malnutrition. Afzal and Dilshad (2018) noted that inflation imposes both economic and social costs because it serves as a major threat to macroeconomic stability, discourages savings, reduces international competitiveness and thus acts as a sinking weight on export performance and reduces the purchasing power of all particularly fixed income groups. Inflation is the friend of none but the enemy of everyone

Todaro and Smith (2012) are of the view that economic growth is an act by which the fruitful and productive capacity of an economy is improved in due course of time, in order to bring about increasing levels of national output having positive affect on income level.

Growth of GDP in Pakistan has not followed a consistent trend rather has fluctuated considerably over the decades. It was agreeable in 1960s and 1980, and early years of 2000s. In the remaining period its growth has not been adequate to meet the demands of the exploding population and Pakistan was constrained to look abroad. Pakistan's economy has lost significant momentum in last few years. Lacklustre economic growth coupled with high inflation rate and low investment levels are among the major problems of Pakistan's economy. Therefore, the objective of this paper is to analyse inflation and economicgrowth scenario based on Macroeconometric modelsof inflation and economic growth in Pakistan for the period 1990-2017.

Main objective of Macro econometric modelling is to explore empirical behaviour of an actual economic system. These models are used to identify the function of the national economies. It provides a common framework to make ex-ante forecasts under alternative experiments, to evaluate policies, and scenarios and for communication (Akbar and Ahmad, 2014). Granger (1999) argues that since economic theories are necessarily simplifying abstractions, translation of theoretical to econometric models must lead to problems like biased coefficient estimates, wrong signs of coefficients, and residual properties that hamper valid inference. Granger argument is not completely supported by the real world experience and practice. The fact is that econometric models do provide valuable information about the underlying problems despite limitations.

Literature on this issue has highlighted important findings. One group of studies hasreported negative and significant relationship between inflation and economic growth (Fischer, 1993; Barro, 1995; Bullard and Keating, 1995; Bruno and Easterly, 1998; Faria and Carneiro, 2001) while other studies have confirmed positive and significant association between inflation and economic growth (Lucas, 1973; Mallik and Chowdhury, 2001; Gillman and Nakov, 2004). These studies supported the hypothesis that low and stable inflation promotes economic growth and vice versa.

\section{Materials and Methods}

\section{Model I: Inflation}

According to Afzal and Awais (2012), inflation is a condition of continually and rapidly rising price level that persists over a long period of time. Once for all increase in prices is not inflation. Expected factors supposed to influence inflation significantly are briefly explained below:

$\mathrm{Y}_{\mathrm{p}}$ : GDP growth measures the aggregate macroeconomic performance of an economy that affects almost all facets of the economy and may be used as representative of important macroeconomic phenomena like political stability, law and order etc. This also influences the inflation and unemployment in the economy and GDP growth may be construed as the mother of all macroeconomic problems. If it is doing well, it will take care of all conceivable problems. Thus, its importance in influencing the inflation is an open secret. 
$\mathrm{M}_{2}$ : money supply is another pivotal variable that decisively affects inflation. Economists disagree on the causes and remedy of inflation. Monetarists hold the view that excessive growth of money supply is the main cause of inflation and thus reducing the money supply will take care of inflation. Its coefficient is expected to positively influence inflation since money supply seems to be the major driver of inflation growth.

ER: Nominal exchange rate also considerably affects inflation because it is the price at which goods and services are imported and exported. Exchange rate stability carries tremendous significance for macroeconomic stability. An economy that succeeds in maintaining exchange rate stability is likely to be stable for itself. Rapid depreciation of Pakistan rupee more recently in 2018 as it reached as high as Rs.130/\$ supports the above view. Current account deficit reached staggering proportions and the debtservice has assumed an ugly preteen. Devaluation increases the price of imported goods that feeds into the general price level. This certainly fuels inflation and it coefficient is expected to be positive.

IM: Imports are an important component of the foreign trade of a country. Since the beginning of the country, it an open secret that imports have far exceeded the exports leading to high trade deficit because Pakistan industry due to import-substitution has remained desperately dependent on imports (Afzal, 2004) and the escalating oil and food prices have aggravated the already bad situation of imports. Increasing imports fuels inflation because of exchange rate depreciation. Therefore, imports are used as a significant variable that leads to high inflation and its coeffient is most likely to be positive.

\section{BD: Budget deficit}

In many developing countries including Pakistan, budget deficit (BD) and current account deficit (CAD) had been the major causes of low economic growth. BD adversely affects growth by reducing national saving and crowds out domestic investment. During 1980s and 1990s the situation did not improve significantly though under IMF pressure government made efforts to reduce the deficit mainly by slashing the development budget. During 2000-07 budget deficit was relatively kept manageable due to external financial assistance received for fighting the War-onterror and privatization proceeds. Budgetary position along with CAD demonstrates that during the three decades (1970s, 1980s and 1990s) total expenditure far exceeded the revenue that had been financed by the domestic and foreign borrowing (Afzal and Shah, 2010). GOP (2006-07) reported that during 1980s and 1990s public debt in Pakistan grew at an average rate of 18 percent and 15 percent respectively much faster than the growth in nominal GDP. Therefore, $\mathrm{BD}$ is still another potential source of aggravating inflation in Pakistan and its coefficient is most likely to be positive.

Therefore, present paper proposes the following model of inflation:

$\ln \pi=\beta_{0}+\beta_{1} \ln Y_{p}+\beta_{2} \ln M_{2}+\beta_{3} \ln E R+\beta_{4} \ln I M+\beta_{5} \ln B D+\mu \ldots$ (1)

All coefficients are expected to have positive sign and $\ln =$ natural logarithm. $\log$ is used to smooth the data and $\pi=$ inflation

\section{Model II: Economic growth}

According to Burney (1986), economic growth is among the major objectives of development policy in every economy. Economic growth depends on basic factors of production (labour and capital), and on technological progress and a combination of institutional and socio-politicalfactors. Moreover, according to the more recent endogenousgrowth theory investment in human capital that comprises expenditure on education and health also makes important contribution.

Investment, social sector, agriculture, industry and imports contribute to economic development. Investment contribution to economic growth is an open secret. So far as imports are concerned, on one side its role is positive because imported capital equipment and production tools will be helpful for high production. On the other hand, reliance on imported goods will decrease the demand for domestic products. Agriculture and industrial production have positive role in economic development, because more and more production will eliminate the issue of low investment. Social sector is also a critical determinant of economic growth. If education, health facilities and tight security is provided, economy may boost up.

The current paper uses the following model for economic growth:

$\ln y=N V+\psi_{2} \ln I M+\psi_{3} \ln A g r i+\psi_{4} \ln I N D S+\psi_{5} \ln H R D+Q \ldots$ (2) 


\section{Where;}

ln= natural logarithm; $y=$ GDP growthis the GDP adjusted for inflation. It is one of the basic indicators used to determine the soundness of the economy. It represents the sum of value of all goods and services in standard currency produced over a definite time period, often referred to as the size of the economy.

INV: gross investment as \% of GDP=since capital stock is not available for most developing countries because of inherent difficulties of measurement, gross investment is used for capital. Investment is net addition to the capital stock and plays central part in augmenting the national income. Investment desperately depends on high savings. Empirical evidence shows that countries have achieved high economic growth because of sufficient savings (Afzal, 2013). Obviously, Investment plays crucial role in augmenting the economic growth and is used an important factor affecting economic growth.

IM: Imports are an important component of the foreign trade of a country. It has been explained above in the inflation model.

Ag: value added by agriculture as \% of GDP= Despite more than 70 years of vigorous industrialization, agriculture is still the mainstay of the economy in terms of its contribution to GDP, employment and foreign exchange earnings. Agriculture also contributes to growth as supplier of raw materials to industry as well as market for industrial products. Not only more than $40 \%$ labour force are engaged in agriculture but also it is host to more than $60 \%$ rural population which is directly or indirectly linked with agriculture.

INDS: value added by industry as \% of GDP= Industrial production is used here as an index or measure of the structural change that accompanies the process of growth and development. Moreover, industrial production can be taken as a proxy for the rate of investment in previous years at which labour and capital have been transferred from agriculture and industry (Afzal, 2004). Agriculture, industry and services are three vital parts of Pakistan GDP. Their share in GDP has varied over the decades. Today industry, agriculture and services share in GDP is $21 \%, 21.8$, and $58.1 \%$ (GOP, 2013-14) respectively. Services were not used as additional explanatory variable because its growth is linked with agriculture and, industry growth. If both are performing well, services sector will also grow.
HRD: human resource development, measured by expenditure made on education and health: Instead of using the growth of labour as factor input, the expenditure on education, training and health is used instead to represent human resource development. Physical capital is important but human capital is more important. Human capital refers to natural ability as well as education and acquired skills. Human capital is produced through formal education, good health, informal training and through on-the-job training. UNDP (2006) report noted that the studies on economic growth have not addressed human development indicators such as life expectancy, infant mortality, literacy. Moreover, these studies have not taken into account appropriate socio-economic factors affecting growth and also institutions. Therefore, expenditure on health and education is taken as proxy for human resource development.

Q: error term that satisfies classical linear regression assumptions

The expected signs of the coefficients of Model-II are positive.

\section{Data}

Annual data for both models variables were obtained from Government of Pakistan (GOP), Economic Survey (1997-98, 2005-06, 2011-12, 20017-18) for the period 1990-2017. HRD comprises government expenditure on education and education and this data were obtained from WDI (2018).

\section{Results and Discussion}

\section{Model I inflation}

This study developed two models dealing with inflation and economic growth. These two macrovariables carry crucial significance in any economy.

Inflation is responsible for a variety of costs in an under developed economies. Keeping in view Pakistan's history, inflation, unemployment and economic growth are major macroeconomic issues. For that very reason the study has chosen inflation as dependent variable. Among many costs, uncertainty seems to be one of the principal costs. It is difficult for an individual, household, business firm and the government to plan safely for future. Therefore, price stability is considered one the most desirable macroeconomic goals. Inflation was measured by consumer price index 
(CPI). It may be argued or pointed out that inflation rate would have served better. It was experimented but the estimation results were not agreeable and reliable. Moreover, taking of logarithm that has been used in all estimations in order to smooth out data, further did not improve the results. That is why CPI has been used elsewhere that improved estimation results. Again, real GDP is a macroeconomic measure of the value of economic output adjusted for price changes i.e. inflation or deflation. Due to inflation, GDP increases but does not actually reflect the true growth in an economy.

Afzal (2010) argued that a country which finds it difficult to stabilize prices and exchange rate is less likely to be stable in it. Table 1 shows OLS results for inflation model. The coefficients signs are according to expectations and significant. There is negative association between GDP and inflation. In traditional financial knowledge, moderate inflation will drive GDP growth, in an environment where income is increasing, money demand will increase. Hence if money supply grows at a rate less than money demand, excess money supply will decrease lowering inflation. Therefore, income rises and inflation decreases; a negative relationship between inflation and growth appears. Increase in GDP leads to fall in inflation and vice versa. For combating inflation, economic performance represented by GDP is enhanced. However, Fischer (1979) has argued that even in the Sidrauski model, inflation can impact real variables in the short run. Fischer has shown that inflation impacts investment positively and consumption negatively, but it does not impact output in the short run for a class of utility functions in which consumption and real money balances are distinguishable. The results show a negative impact of inflation on output in the short run.

Table 1: Model-I-Inflation.

$\begin{array}{lllll}\text { Variable } & \text { Coefficient } & \text { Std. error } & \text { t-Statistic } & \text { Prob. } \\ \text { C } & -1.06 & 0.42 & -2.55 & 0.0183 \\ \text { Lngdpg } & -0.07 & 0.03 & -2.56 & 0.0179 \\ \text { Lner } & 0.40 & 0.16 & 2.45 & 0.0234 \\ \text { lnm }_{2} & 0.05 & 0.02 & 2.55 & 0.0188 \\ \text { Lnimports } & 0.51 & 0.12 & 4.30 & 0.0003 \\ \text { Lnbd } & -0.17 & 0.09 & -1.83 & 0.0809 \\ \mathrm{R}^{2} & 0.96 & \mathrm{DW}=2.003 & \text { F-statistic } & 127.36(0.000)\end{array}$

Exchange rate has the expected positive impact on inflation. Depreciation (an increase in the price of domestic currency in terms of foreign currency) of the exchange rate is inflationary. One unit increase in exchange rate results in 0.39 units increase in inflation. Exchange rate in Pakistan has been rapidly depreciating rapidly that is causing inflation. This result is also consistent with economic theory as well as previous studies which concluded that the exchange rate has a significant effect on inflation, therefore any decision to change current monetary strategy i.e., applying fixed or flexible exchange rate must also take into consideration the associated costs and benefits (Fetai et al.2016).

The $\mathrm{M}_{2}$ (money supply) coefficient is significantly positive that shows that increase in money supply feeds inflation and supports the Monetarists view that inflation is primarily a monetary phenomenon. Classical economists emphasized that money was neutral in the short-run as well as long-run. Keynes and Milton Friedman were of the view that money was not neutral in the short-run rather it does affect output. However, money supply is a powerful lever that propels inflation. To fight inflation, excessive growth of money supply is kept under control. Thus, despite the fact that long-run results support Sidrauski's super neutrality of money, short-run results cast doubt on the short-run implications of Sidrauski's model for separable utility functions (Sidrauski, 1967).

Imports in Pakistan are another potential factor that breeds inflation sufficiently. Its coefficient is highly significant. 1-unit increase in imports causes 0.50 units increase in inflation. Pakistan exchange rate has seen precipitate depreciation more recently that one hand has escalated imports cost and on the other hand, has increased inflation and mounting trade deficit. Exports growth has not kept pace with imports growth. During the current decade, exports have almost remained negative or stagnant (GOP, 2017-18).

Budget deficit (BD) is another culprit responsible for increasing inflation. To meet $\mathrm{BD}$, government has few choices. Increase in taxes and Tax-GDP ratio, borrowing abroad or resort to printing press. Government of Pakistan since the last decade even before that had been borrowing from the banking system as well as printing money regardless of the harmful effects on macro-economy. All these reinforce each other and escalate inflation. It seems difficult 
that GOP succeeds in curtailing the BD and current account deficit because of the rampant corruption and money-laundering because of political compulsions. Soomro and Memon (2008) showed empirical answer of the question whether or not Pakistan's inflation is significantly related to budget deficit. Models develop for this study is consonance with economic theory. Further while studying the sources of inflation, the result does suggest that monetary growth, federal deficit, import prices and weighted average lending rate have significant impact on CPI. Although, decrease in imports and decrease in budget deficit can mitigate inflation rate. Restrictive fiscal policy along with tight monetary policy appears to be a necessary ingredient in anti inflationary policy.

Except imports, rest of the coefficients are positive and significant suggesting the paramount significance of human resource development, investment, and value-added by both agriculture and industry. This suggests that if the policy makers attach genuine attention to these factors, it is expected that Pakistan economy will perform reasonably well. Exports also promote economic growth. Unfortunately, exports have not paid an enviable role with the exception of few years due to Korean War and massive devaluation of the exchange rate in 1972. Exports also contribute to economic growth but as the history of Pakistan shows that exports have not contributed immensely to economic growth of Pakistan. Afzal and Ali (2008) have argued based on historical evidence that growth in GDP had led exports growth rather than the other way round. Knack and Keefer's (1994) examined that growth also rises in response to a contemporaneous improvement in the terms of trade, measured by the growth rate of the ratio of export to import prices. Keeping the same idea Khan et al. (2012) examined that both exports and imports are essential for economic growth of Pakistan. The study further reveals that economic growth has an important impact on both imports and exports.

Keeping in view the above results, according to Azra et al. (2013), being an agricultural economy, value added by agriculture plays an important role in growth of the economy. Almsafir and Morzuki (2015), by using time series data for a period of 20 years from 1994 to 2013 (from the World Bank), applied multi regression model to analyse the relationship between FDI, public investment, private investment and gross domestic product (GDP). The results show that both public and private investments are significantly correlated with GDP while FDI is insignificantly correlated with GDP. It is noted that all the independent variables are positively related to the dependent variable with public investment has the most influence on GDP, suggesting that investment spur economic growth of Malaysia.

Table 2 shows that except imports, rest of the coefficients are positive as well as significant suggesting the paramount significance of human resource development, investment, and value-added by both agriculture and industry. This suggests that if the policy makers attach genuine attention to these factors, it is expected that Pakistan economy will perform reasonably well. Exports also promote economic growth. Unfortunately, exports have not played an enviable role with the exception of few years due to Korean War and massive of exchange rate devaluation in 1972 .

Table 2: Empirical results: Model-II (economic growth).

$\begin{array}{lllll}\text { Variable(log) } & \text { Coefficient } & \text { Std. error } & \text { t-Statistic } & \text { Prob. } \\ \text { C } & -10.55 & 3.11 & -3.39 & 0.0026 \\ \text { Imports } & 0.059 & 0.19 & 0.31 & 0.7563 \\ \text { Hrd } & 0.25 & 0.11 & 2.18 & 0.0398 \\ \text { Agva } & 1.23 & 0.39 & 3.13 & 0.0049 \\ \text { industryva } & 1.85 & 0.42 & 4.33 & 0.0003 \\ \text { Inv } & 1.13 & 0.23 & 4.93 & 0.0001 \\ \mathrm{R}^{2} & 0.992 & \mathrm{DW}=1.54 & \text { F-statistic } & 1174.51 \\ & & & & (0.000)\end{array}$

\section{Specification and diagnostic tests}

Ramsey Reset is about functional specification that is the regression model is correctly specified. These tests were obtained by Eviews 8. For the three models, $\mathrm{F}$-statistic and t-statistic are insignificant meaning that these models do not suffer from functional misspecification. Breusch-Godfrey serial correlation LM test, Heteroscedasticity (White) and Normality JB statistic are all insignificant meaning that the underlying models do not suffer from major econometric problems and these results suggest statistical appropriateness and soundness of the estimated models (Table 3). Multicollinearity is indicated by the VIF (Variance Inflation Factor) that exceeds 10 (Gujarati, 2004). However, on the average results do not violate the assumption substantially. 
Table 3: Specification and diagnostic tests.

\begin{tabular}{|c|c|c|c|c|}
\hline Test & $\begin{array}{l}\text { Model-I } \\
\text { (inflation) }\end{array}$ & $\begin{array}{l}\text { Model-II } \\
\text { (Growth) }\end{array}$ & $\begin{array}{l}\text { Model-I } \\
\text { (Inflation) } \\
\text { VIF }\end{array}$ & $\begin{array}{l}\text { Model-II } \\
\text { (Growth) } \\
\text { VIF }\end{array}$ \\
\hline Ramsey reset & $\begin{array}{l}F(1,20)=2.11 \\
(0.1613)\end{array}$ & $\begin{array}{l}F(1,21)=0.78 \\
(0.38)\end{array}$ & 1.276708 & 220.2745 \\
\hline LM test & $\begin{array}{l}\mathrm{F}(2,19)=0.11 \\
(0.8968)\end{array}$ & $\begin{array}{l}F(2,20)=0.69 \\
(0.5092)\end{array}$ & 12.84612 & 1.446688 \\
\hline $\begin{array}{l}\text { Heteroscedas- } \\
\text { ticity (White) }\end{array}$ & $\begin{array}{l}\mathrm{F}(20,6)=2.21 \\
(0.1645)\end{array}$ & $\begin{array}{l}F(5,22)=0.50 \\
(0.7704)\end{array}$ & 1.449476 & 5.838936 \\
\hline \multirow[t]{2}{*}{$\begin{array}{l}\text { Normality } \\
\text { JB statistic }\end{array}$} & $\begin{array}{l}\text { Chi-square } \\
(2)=1.22 \\
(0.5431)\end{array}$ & $\begin{array}{l}\text { Chi-square } \\
(2)=0.76 \\
(0.68)\end{array}$ & 36.03223 & 3.133398 \\
\hline & & & 18.99821 & 265.7021 \\
\hline
\end{tabular}

\section{Parameters stability}

To establish the stability of the parameters Chow Breakpoint test was used which is of structural stability. Two sub-samples 1991-2000 and 2002-2017 were chosen. 1991 was chosen as a breakpoint since Pakistan embarked on a comprehensive macroeconomic reform and similarly in 2002 Pakistan entered the War-onterror. Both have affected Pakistan economy.

Both F and LR statistic are insignificant (Table 4) for both periods suggesting that inflation (Model-I) did show stability during 1990-2000 and 20012017 periods that implies that the inflation wasnot significantly affected by the macroeconomic reforms and War-on-terror. GDP experienced significant change based on LR-statistic during both periods (1991-2000 and 2002-2017). This supported the low average growth rate of GDP during more recent period.

\section{Table 4: Chow breakpoint test.}

$\begin{array}{lll}\text { Period } & \text { Model-I (inflation) } & \text { Model-II (Growth) } \\ 2000 & \mathrm{~F}(6,15)=0.69 & \mathrm{~F}(6,16)=0.39 \\ & (0.6606) & (0.8718) \\ & \mathrm{LR}=6.58 & \mathrm{LR}=3.86 \\ & (\chi 2(6)=0.3607) & (\chi 2(6)=0.6952) \\ 2002 & \mathrm{~F}(6,15)=1.33 & \mathrm{~F}(6,16)=0.60 \\ & (0.3004) & (0.7230) \\ & \mathrm{LR}=11.57 & \mathrm{LR}=5.72 \\ & (\chi 2(6)=0.0721) & (\chi 2(6)=04549)\end{array}$

\section{Conclusions and Recommendations}

This paper made an econometric investigation of inflation and economic growth for the period 19902017. Inflation like investment and employment is an important macro variable which is ofmuch concern to policy makers and politicians. Money supply, imports, exchange rate andbudget deficit were found to be the major causes of inflation in Pakistan.

There is negative correlation between GDP and inflation. Increase in GDP is expected to lead to areduction in inflation. To combat inflation, unwarranted growth of money supply is kept under control and the exchange is stabilized. It is less likely that imports are reduced to alleviate inflation due to economy needs. It appears difficult that GOP succeeds in curtailing the $\mathrm{BD}$ because of the rampant corruption and money-laundering.

Human resource development coupled with investment and value-added by both agriculture and industry contributed significantly to economic growth. Should the policy makers attach genuine attention to these factors, it is expected that Pakistan economy will perform reasonably well. Specification and diagnostic tests revealed the appropriateness and soundness of the inflation and economic growth models. CPI showed stabilityin both periodsbut GDP did not demonstrate in the second period.

\section{Novelty Statement}

The research shows a negative impact of inflation on output in the short run.

\section{Author's Contribution}

Azra: Conducted the research as part of $\mathrm{PhD}$ work. Muhammad Afzal: $\mathrm{PhD}$ supervisor and supervised the study.

Dilawar Khan: Helped in data analysis.

\section{Conflict of interest}

The authors have declared no conflict of interest.

\section{References}

Afzal,M.and D.Ahmad.2018. Stabilization policies and the domestic output response: Evidence from Pakistan. Int. J. Adv. Appl. Sci., 5(4): 6-13. https://doi.org/10.21833/ijaas.2018.04.002

Afzal, M.2013. National savings and foreign capital in Pakistan. Appl. Econ. Int. Dev., 13(2): 197206.

Afzal, M. and S. Awais. 2012. Inflationunemployment trade off: Evidence from Pakistan. J. Glob. Econ., 8(1): 21-32. 
Afzal, M. and S.Z.A. Shah. 2010. Twin deficits scenario: Evidence from Pakistan. Middle East Bus. Econ. Rev., 22(2): 59-79.

Afzal, M. 2010. Exchange rates and reserves in Asian Countries: Causality test. Glob. Econ. Rev., 39(2): 215-223. https://doi.org/10.1080/ 1226508X.2010.483839

Afzal, M. and Ali. K. 2008. A historical evaluation of export-led growth policy in Pakistan. Lahore J. Policy Stud., 2(1): 69-82.

Afzal, M. 2004. Exports-economic growth nexus: Pakistan's experience. Indian J. Bus. Econ., 3(2): 315-340.

Akbar, M. and Ahmad. E. 2014. A review of macroeconometric modelling practice. Forman J. Econ. Stud., 10: 17-51. https://doi. org/10.32368/FJES.20141002

Alderman, H. 2005. Linkages between poverty reduction strategies and child nutrition: An Asian perspective. Econ. Polit. Wkly., 40(46): 4837- 4842.

Almsafir, M.K. and Z.M. Morzuki. 2015. The relationship between investment and economic growth in Malaysia. J. Empirical Econ., 4(2): 116-126.

Azra, D. Khan, E. Ahmed and S.S. Ahmed. 2013. Agriculture and Economic Growth: Empirical Evidence from Pakistan. Sarhad Univ. Int. J. Basic Appl. Sci., 1(1): 307-313.

Barro, R.J. 1991. Economic growth in a cross section of countries. Q. J. Econ., 106(2): 407443. https://doi.org/10.2307/2937943

Barro, R.J. 1995. Inflation and economic growth. Natl. Bur. Econ. Res., 14(1): 121-144. https:// doi.org/10.3386/w5326

Bashir, F., S. Nawaz, K. Yasin, U. Khursheed, J. Khan and M.J. Qureshi. 2011. Determinants of inflation in Pakistan: An econometric analysis using Johansen co-integration approach. Aust. J. Bus. Manage. Res., 1(5): 71-82.

Bleaney, M. and D. Fielding. 2002. Exchange rate regimes, inflation and output volatility in developing countries. J. Dev. Econ., 68(1): 233-245. https://doi.org/10.1016/S03043878(02)00002-0

Boyd, J.H., R. Levine and B.D. Smith. 2001. The impact of inflation on financial sector performance. J. Monet. Econ., 47(2): 221248. 3932(01)00049-6

Bullard, J. and J.W. Keating. 1995. The long-run
Relationship between inflation and output in post-war economies. J. Monet. Econ., 36: 477-496. 3932(95)01227-3

Bruno, M. and W. Easterly. 1998. Inflation crises and long-run growth. J. Monet. Econ., 41(1): 3-26. https://doi.org/10.1016/S03043932(97)00063-9

Burney, N.A. 1986. Sources of Pakistan's economic growth. Pak. Dev. Rev., 25(4): 573-589. https:// doi.org/10.30541/v25i4pp.573-589

Faria, J.R. and F.G. Carneiro. 2001. Does high inflation affect growth in the long and short run? J. Appl. Econ., 4(1): 89-105. https://doi.or $\mathrm{g} / 10.1080 / 15140326.2001 .12040559$

Fetai, B., P.S. Koku, A. Caushi and A. Fetai. 2016. The relationship between exchange rate and inflation: The case of western Balkans countries. J. Bus. Econ. Finance. 5(4): 360-364. https:// doi.org/10.17261/Pressacademia.2017.358

Fischer, S. 1979. Capital accumulation on the transition path in a monetary optimizing model. Econometrica, 47(6): 1433-1439. https://doi. org/10.2307/1914010

Fischer, S. 1993. The role of Macroeconomic factors in growth. J. Monet. Econ., 32(3): 485-512. $\quad$ https://doi.org/10.1016/03043932(93)90027-D

Gillman, M. and A. Nakov. 2004. Granger causality of the inflation-growth mirror in accession countries. Econ. Transition., 12(4): 653-681. https://doi.org/10.1111/j.09670750.2004.00198.x

GOP, 1999. Economic survey (various issues). Islamabad, Ministry of Finance, Economic Advisor Wing.

GOP (Government of Pakistan), 2006-2007. Economic Survey. Islamabad, Ministry of Finance, Economic Advisor Wing.

GOP (Government of Pakistan), 2011-2012. Economic Survey. Islamabad, Ministry of Finance, Economic Advisor Wing.

GOP (Government of Pakistan), 2013-2014. Economic Survey. Islamabad, Ministry of Finance, Economic Advisor Wing.

GOP (Government of Pakistan), 2017-2018. Economic Survey. Islamabad, Ministry of Finance, Economic Advisor Wing.

Granger, C.W.J. 1999. Empirical modelling in economics: Specification and evaluation. Cambridge University Press, Cambridge. 
Gujarati, D. 2004. Basic econometrics. McGraw Hill

Hussain,M.2005. Inflation and growth: Estimation of threshold point for Pakistan. Pak. Bus. Rev., 7(3): 1-15.

Iqbal, Z. and G.M. Zahid. 1998. Macroeconomic determinants of economic growth in Pakistan. Pak. Dev. Rev., 37(2): 125-148. https://doi. org/10.30541/v37i2pp.125-148

Jaffri, A.A. 2010. Exchange rate pass-through to consumer prices in Pakistan: Does misalignment matter? Pak. Dev. Rev., 49(1): 19-35. https:// doi.org/10.30541/v49i1pp.19-35

Khan, A.A., Q.M. Ahmed and K. Hyder. 2007. Determinants of recent inflation in Pakistan. Soc. Policy Dev. Center, Karachi. MPRA Paper No.16254 posted 15. July 2009 13:36 UTC.

Khan, A.A., S.K.H. Bukhari and Q.M. Ahmad. 2009. Determinants of recent inflation in Pakistan. Res. Rep. No. 66. Karachi, Pakistan: Soc. Policy Dev. Center.

Khan, D., A. Umar, M.E. Ahmad and Y. Shoukat. 2012. Exports, imports and economic growth nexus: Time series evidence from Pakistan. World Appl. Sci. J., (WASJ), 18(4): 538-542.

Knack, S. and P. Kafeer. 1994. Institutions and economic performance: Cross country tests using alternative institutional measures. Econ. Polit., 7(3): 207-227. https://doi. org/10.1111/j.1468-0343.1995.tb00111.x

Lucas, R. 1973. Some international evidence on output-inflation tradeoffs. Am. Econ. Rev., 63(3): 326-334.

Mallik, G. and A. Chowdhury. 2001. Inflation and Economic Growth: Evidence from South Asian countries, Asian Pac. Dev. J., 8(1): 123-135.

Lim, C.H. and L. Papi. 1997. An econometric analysis of the determinants of inflation in Turkey. IMF Working paper no. 170: 1-32. https://doi.org/10.5089/9781451858389.001

Laryea, S.A. and U.R. Sumaila. 2001. Determinants of inflation in Tanzania. Michelsen Inst. Dev. Stud. Hum. Rights, WP-12: $1-17$.

Pindyck, R.S. and A. Solimano. 1993. Economic instability and aggregate investment. NBER Macroeconomics Annual, MIT Press, Cambridge, MA, pp. 259-303. https://doi. org $/ 10.1086 / 654223$

Qayyum, A. 2006. Money, inflation, and growth in Pakistan. Pak. Dev. Rev., 45(2): 203-212. https://doi.org/10.30541/v45i2pp.203-212

Riaz, S.I. and T. Anwar. 2012. The public debt and growth in Pakistan: A time series anaylsis from 1972-2010. Acad. Res. Int., 2(1): 535-544.

Sidrauski, M. 1967. Rational choice and patterns of growth in a monetary economy. Am. Econ. Rev., 57(2): 534-544.

Soomro, R.H. and S.A. Memon. 2008. Empirical study of relationship between budget deficit and inflation: A case study of Pakistan. J. Independent Study Res. Manage. Soc. Sci. Res., 6(1): 22-26. https://doi.org/10.31384/ jisrmsse/2008.06.1.4

Taslim, M.A. 1980. Inflation in Bangladesh: A re-examination of the structuralist monetarist controversy. Bangladesh Dev. Stud., 10(1): 100116.

Todaro, M.P. and S.T. Smith. 2012. Development Economics. Addison-Wesley.

UNDP. 2006. Human development report, 2006.

World Bank. 2018.World development indicators. New York. 